\title{
DISIPASI ENERGI KINETIK PASANG SURUT BAROTROPIK DAN BAROKLINIK DI LAUT SULAWESI
}

\section{TIDAL BAROTROPIC AND BAROCLINIC KINETIC ENERGY DISSIPATION IN THE SULAWESI SEA}

\author{
Hadi Hermansyah ${ }^{1,2^{*}}$, Dwiyoga Nugroho ${ }^{3}$, Agus S. Atmadipoera ${ }^{4}$, Tri Prartono ${ }^{4}$, \\ Indra Jaya ${ }^{4}$, dan Fadli Syamsudin ${ }^{5}$ \\ ${ }^{1}$ Politeknik Negeri Balikpapan, Kalimantan Timur; *E-mail: hadi.hermansyah@poltekba.ac.id \\ ${ }^{2}$ Prodi Ilmu Kelautan, Sekolah Pasca Sarjana IPB \\ ${ }^{3}$ Pusat Riset Teknologi Kelautan, Balitbang KP-KKP, Jakarta \\ ${ }^{4}$ Departemen Ilmu dan Teknlogi kelautan, FPIK-IPB, Bogor \\ ${ }^{5}$ Badan Pengkajian dan Penerapan Teknologi (BPPT) RI, Jakarta
}

\begin{abstract}
Sulawesi Sea is one of the exit passages of Indonesian Throughflow (ITF) which conveys hotspot of strong internal tidal energy. High tidal currents that interact with rough topography will generate strong internal waves. Dissipation of internal tides will cause mixing that will have an important effect on climate change systems and marine resources. The purpose of this research was to quantify internal wave dynamics and energetics in the Sulawesi Sea using a numerical modeling of the NEMO's three-dimensional physical circulation model. The results showed that internal waves were generated in the Sulu and Sangihe-Talaud Island Chains with an energy conversion value of more than $10^{-3} \mathrm{Wm}^{-2}$ and propagated into the Sulawesi Sea basin area. The energy dissipation that occurred at the generation center was around $10.8 \mathrm{GW}$ and propagateto the generation sites (near-fieldarea) and the far-field (basin area). Dissipation occurs in the generation sites approximately 25\% (5 GW), there is an increase in baroclinic energy dissipation when internal waves propagate away from the central generation area with values varying from 1.4 to $4.8 \mathrm{GW}$. In areas with a distance of $36 \mathrm{~km}$ to $54 \mathrm{~km}$ there is a decrease in baroclinic energy dissipation, a strong signal from the Sangihe-Talaud Islands gradually declined during propagation from $10^{-2}$ to $10^{-3} \mathrm{~W} / \mathrm{m}^{2}$.
\end{abstract}

Keywords: INDESO, internal tides, mixing, NEMO, water masses transformation, normal modes

\begin{abstract}
ABSTRAK
Laut Sulawesi merupakan salah satu jalur penting perlintasan Arus Lintas Indonesia (Arlindo) yang memiliki energi pasang surut internal yang kuat. Arus pasang surut tinggi yang berinteraksi dengan topografi yang kasar akan menciptakan gelombang internal yang kuat. Disipasi dari pasang surut internal akan menyebabkan terjadinya percampuran yang akan memberikan efek penting untuk sistem perubahan iklim dan sumber daya laut. Tujuan dari penelitian ini adalah untuk mengkuantifikasi dinamika dan energetik gelombang internal di Laut Sulawesi dengan pendekatan pemodelan laut tiga dimensi NEMO. Hasil penelitian menunjukkan bahwa gelombang internal dibangkitkan pada daerah Kepulauan Sulu dan Sangihe-Talaud dengan nilai konversi energi lebih dari $10^{-3} \mathrm{Wm}^{-2}$ dan berpropagasi masuk ke area basin Laut Sulawesi. Disipasi energi yang terjadi pada pusat pembangkitan berkisar 10,8 GW dan berpopagasi pada area dekat pusat pembangkitan dan area basin Laut Sulawesi. Sekitar 25\% (5 GW) didisipasi terjadi dekat pusat pembangkitan, peningkatan disipasi energi baroklinik terjadi pada saat gelombang internal berpopagasi menjauhi daerah pusat pembangkitan dengan nilai yang bervariasi antara 1,4 sampai 4,8 GW. Daerah dengan jarak $36 \mathrm{~km}$ sampai $54 \mathrm{~km}$ terjadi penurunan disipasi energi baroklinik, signal yang kuat dari Kepulaun SangiheTalaud berangsur menurun pada saat propagasi dari $10^{-2}$ sampai $10^{-3} \mathrm{~W} / \mathrm{m}^{2}$.
\end{abstract}

Kata kunci: INDESO, pasang surut internal, percampuran, NEMO, transformasi massa air, normal modes 


\section{PENDAHULUAN}

Lautan mencakup sekitar $71 \%$ permukaan bumi, sehingga menjadikan laut sebagai pengumpul energi terbesar di dunia. Sisi lain, air laut bergerak secara konstan pada skala yang berbeda mulai dari arus laut skala besar hingga sentrifugal turbulen. Gerakan-gerakan ini menciptakan banyak energi kinetik di lautan (Kang dan Fringer, 2012). Oleh karena itu, pemahaman yang lebih baik tentang proses fisik yang mengatur pergerakan laut sangat penting untuk memanfaatkan energi laut secara lebih efisien.

Pasang surut adalah salah satu sumber utama energi untuk percampuran di dalam lautan. Energi pasang surut barotropik diubah menjadi baroklinik melalui serangkaian proses pencampuran yang penting. Ketika aliran pasang surut barotropik mengalir di atas fitur topografi yang kasar, sebagian dari energi barotropik akan langsung melalui pencampuran lokal, sementara bagian lainnya diubah menjadi energi baroklinik melalui pembangkitan pasang surut internal (baroklinik). Energi baroklinik yang dihasilkan ini didisipasi baik secara lokal atau memancar ke laut terbuka, dan kemudian mengalir ke skala yang lebih kecil di sepanjang spektrum gelombang internal dan akhirnya berubah menjadi turbulensi laut dalam.

Beberapa dekade terakhir upaya signifikan telah dilakukan untuk memahami proses pencampuran pasang surut dan distribusi energi yang terkait. Munk dan Wunsch (1998) menjelaskan budget fluksenergi pasangsurut global, dari 3,5 TW $(1 \mathrm{TW}=1012 \mathrm{~W})$ total energi pasang surut yang hilang di lautan, sekitar 2,6 TW didisipasikan di laut yang dangkal melalui gesekan dasar, sementara sisanya sebagian hilang di laut dalam. Egbert dan Ray (2000, 2001) telah mengkonfirmasi bahwa sekitar 1 $\mathrm{TW}$, atau $25-30 \%$ dari total energi pasang surut global hilang di laut dalam. Mereka menemukan bahwa gelombang tersebut kehilangan lebih banyak energi di lautan terbuka, umumnya di daerah-daerah dengan fitur topografi yang kasar. Observasi lapangan juga menunjukkan bahwa pencampuran turbulen mempunyai nilai beberapa kali lebih besar pada topografi kasar daripada di atas dataran abyssal yang halus (Polzin et al., 1997). Bukti ini cukup mampu menjelaskan bahwa arus internal sebagai sumber utama energi untuk pencampuran laut dalam. Investigasi baik analitik maupun numerik juga telah dilakukan untuk memperkirakan budget energi pasang surut (Carter, 2010; Jachec et al., 2006; Niwa dan Hibiya, 2004; St Laurent and Garrett, 2002). Konversi energi dari pasang surut barotropik ke gelombang internal di laut dalam diperkirakan sekitar 1TW-1,25 TW (Egbert dan Ray, 2001). Gelombang internal dapat mentransfer energinya ke skala yang lebih kecil (skala turbulen) dan menyebabkan pencampuran di lautan.

Kajian mendalam tentang energetik pasang surut telah dilakukan oleh Le Provost (2003) yang menjelaskan bahwa laju lokal disipasi pasang surut dari input energi pasang surut hilang terutama akibat adanya gesekan dasar dan sisanya adalah ditransfer ke arus internal. Proses ini juga dapat dijelaskan dengan baik dalam model spectral barotropic boussinesq inviscid menggunakan data FES2004 (Lyard et al., 2006).

Kajian dengan pendekatan pemodelan pasang surut tiga dimensi Ocean Global Circultaion Model (OGCM) telah dilakukan oleh Arbic et al. (2010); Carter et al. (2012); Kang dan Fringer (2012); Niwa dan Hibiya (2001a); Nagai dan Hibiya (2015); Zilberman et al. (2009). Pengembangan lanjutan secara komputasi memungkinkan perhitungan energi pasang surut dilakukan dalam model resolusi tiga dimensi yang lebih halus. Input pasang surut barotropik akan kehilangan energinya terutama karena adanya gesekan dasar dan diubah menjadi arus internal ketika aliran barotropik melalui variasi topografi seperti ridge (puncak bukit) dan berpropagasi jauh ke lautan terbuka 
(Bell, 1975; Garret and Kunze, 2007; Carter et al., 2012).

Sangat menarik untuk dicatat bahwa meskipun kajian transfer energi dari barotropik ke gelombang internal dapat secara eksplisit dipecahkan di OGCM, namun model ini juga menghasilkan energi palsu karena viskositas dan difusi numerik, selanjutnya profil stratifikasi tiga dimensi dalam model memungkinkan pembangkitan pasang surut internal merambat dan menghilang dalam arah vertikal dan horizontal sehingga peran energetik dan pencampuran pasang surut tidak dapat dilihat dengan jelas. Sementara dalam model INDO12 yang mencakup perairan Asia Tenggara, banyak penelitian telah dilakukan dan fokus pada pembangkitan, propagasi, dan disipasi gelombang internal misalnya di Selat Luzon yang melintasi Laut Cina Selatan (Alford et al., 2015; Jan et al., 2007a; 2008b; Wang et al., 2016) dan di Laut Indonesia (Robertson dan Ffield, 2008).

Secara khusus, fokus kajian ini adalah untuk mengevaluasi mekanisme pembangkitan dan propagasi gelombang internal pada area Laut Sulawesi, serta kuantifikasi disipasi energi pasang surut dengan menggunakan model numerik Nucleus for European Modelling of the Ocean (NEMO). Berdasarkan beberapa hal tersebut tujuan dari penelitian ini adalah mengkuantifikasi dinamika dan energetik gelombang internal di Laut Sulawesi dengan pendekatan pemodelan numerik.

\section{METODE PENELITIAN}

\subsection{Lokasi dan Waktu Penelitian}

Penelitian ini dilakukan pada bulan November 2017-Maret 2018 dengan domain model berada di laut Sulawesi dengan koordinat $0,5^{\circ} \mathrm{N}$ hingga $7^{\circ} \mathrm{N}$ dan $117^{\circ} \mathrm{E}$ hingga $127^{\circ} \mathrm{E}$ (Gambar 1). Domain model dipilih berdasarkan daerah yang mencakup wilayah pembangkitan dan propagasi Gelombang Internal. Pemrosesan data dilaksanakan di Laboratorium Oseanografi
Fisika, Departemen Ilmu dan Teknologi Kelautan, Fakultas Perikanan dan Ilmu Kelautan, Institut Pertanian Bogor dan Pusat Riset Teknologi Kelautan, Balitbang KPKKP.

\subsection{Sumber Data}

Penelitian ini menggunakan konfigurasi model INDESO modifikasi Tranchant et al. (2016). Resolusi horizontal adalah $1 / 12^{\circ}$ dan domain meliputi perairan Laut Sulawesi yang diketahui sebagai wilayah pembangkitan pasang surut internal yang kuat (gambar 1). Model ini memiliki 50 level vertikal dari resolusi beberapa meter pada lapisan permukaan dan $250 \mathrm{~m}$ pada lapisan bawah. Kondisi awal dan kondisi batas terbuka diperoleh melalui "Mercator-Ocean Global Ocean Forecasting System" pada 1/4 (PSY3V3R3). Kondisi ini meliputi temperatur, salinitas, arus dan Sea Surface Height (SSH). Kondisi batas terbuka berada pada 10 grid point $\left(\sim 1^{\circ}\right)$. Data Pembangkit atmosfir diperoleh dari European Center (ECMWF) dengan frekuensi tinggi (3h).

\subsection{Pengaturan Model}

Model Output NEMO (Madec, 2008) digunakan untuk simulasi dalam konfigurasi tiga dimensi. Simulasi menggunakan domain yang sama dengan INDO12 (Tranchant et al., 2016; dan Nugroho et al., 2017). Grid numerik dibangun dari grid ORCA12 (Konfigurasi Global $1 / 12^{\circ}$ ) dan resolusi grid hampir seragam $\sim 9 \mathrm{~km}$ dalam arah $x$ dan $y$.

Model yang digunakan dalam penelitian ini menampilkan tiga simulasi dan dilakukan dalam konfigurasi tiga dimensi. Model dijalankan selama 31 hari dengan pertimbangan sebagai waktu ideal $2 \mathrm{n}+1$ siklus pasang surut. Persamaan model dan konfigurasi yang digunakan sesuai dengan Tranchant et al. (2016).

\subsubsection{Kasus Realistik}

Kajian ini kasus realistik direpresentasikan oleh geometri garis pantai yang kompleks, kekuatan pasang surut, dan 


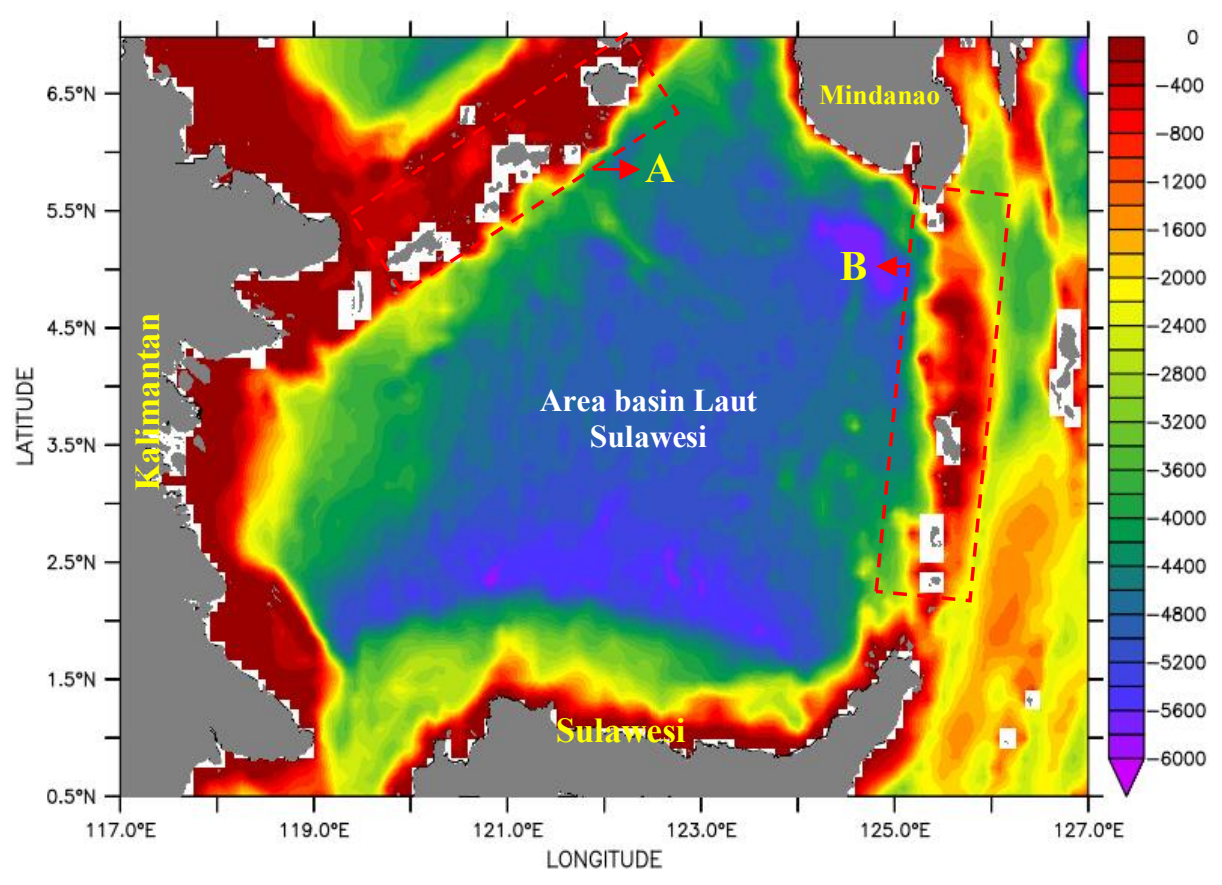

Gambar 1. Domain model Laut Sulawesi (A = Rangkaian Kepulauan Sulu, B = Rangkaian Kepulauan Sangihe-Talaud).

pembalikan musiman dari angin monsoon. Pemodelan sirkulasi yang realistis di perairan Indonesia membantu memahami peran penting dari ARLINDO dalam skala global. ARLINDO membawa air dari Pasifik tropis ke Samudera Hindia di wilayah di mana (i) batimetri dasar Laut Sulawesi yang kompleks (lihat Gambar 1), (ii) banyak selat sempit dan interior basin yang dalam (semi-tertutup) dengan ke kedalaman mencapai $5900 \mathrm{~m}$ dan (iii) pencampuran pasang surut memungkinkan transformasi sumber air Pasifik masuk ke dalam massa air yang berbeda.

Model menggunakan nilai awal dari potensial suhu dan salinitas dalam tiga dimensi yang merepresentasikan stratifikasi musim panas dan diatur untuk menjadi sama dengan stratifikasi INDO12 pada 30 Juni 2010. Densitas dihitung dari persamaan yang sudah ditetapkan. Seluruh permukaan dan forcing densitas diambil sama seperti dalam simulasi INDO12 selama periode Juli 2010. Hasil keluaran model tiga dimensi yang ditetapkan yaitu kecepatan (U, V dan W), potensial densitas insitu (T, S), dan vertikal difusivitas dari model GLS, sedangkan keluaran model dua dimensi diatur untuk kecepatan rata-rata horisontal $(u, v)$ dan tinggi permukaan laut (SSH). Persamaan potensial pasang surut dalam model INDO12 untuk pasang surut semidiurnal diberikan melalui persamaan:

$\eta_{e q}=H_{n} \cos ^{2} \phi \cos \left(\omega_{n} t+2 \chi+V_{n}\right) \ldots$

Pasang surut diurnal diberikan oleh:

$\eta_{e q}=H_{n} \sin 2 \phi \cos \left(\omega_{n} t+\chi+V_{n}\right) \ldots$

Keterangan: $\chi$ dan $\phi$ masing-masing didefinisikan sebagai derajat bujur dan derajat lintang, $\omega$ adalah frekuensi, dan $V_{n}$ merupakan sudut fase argumen astronomi. Kondisi batas dalam dua dan tiga dimensi menggunakan kondisi yang sama. Kondisi batas ini adalah yang paling cocok di wilayah di mana gelombang gravitasi permukaan menjadi dominan (Nugroho et al., 2017). Berbeda dengan operasional model global lainnya yang tidak memperhitungkan gesekan dasar topografi. Model ini, pasang surut internal secara penuh dibangkitkan 
melalui penyelesaian persamaan permukaan bebas non-linear.

Model difusi lateral pada momentum menggunakan operator bi-laplacian dengan konstanta waktu horizontal konstan 1,25x $10^{10} \mathrm{~m}^{2} \mathrm{~s}^{-1}$. Parameterisasi fisik secara spesifik untuk skema skala sub grid menggunakan model turbulensi GenericLength Scale (GLS) dan menerapkan persamaan non-linear pada tegangan bawah. Gesekan dasar $C d$ diatur menggunakan koefisien gesekan non-linear yang ditentukan dengan menggunakan persamaan:

$$
C D=M A X\left[\frac{\kappa^{2}}{\left(\ln \left(h_{b o t} / h_{\text {bro }}\right)\right)^{2}}, b_{\text {fric }}\right] \ldots \ldots \ldots
$$

Keterangan : $K=0,4$ adalah konstanta von Karman, $h_{\text {bot }}$ adalah ketebalan grid bawah. $h_{\text {bro }}$ adalah panjang kekasaran dan $b_{\text {fric }}$ adalah koefisien gesekan. Nilai $b_{\text {fric }}$ dan $h_{\text {bro }}$ diambil $2,5 e^{-3} \mathrm{~m}^{2} / \mathrm{s}^{2}$ dan $3 \mathrm{e}^{-3} \mathrm{~m}$. Forcing Astronomi digunakan dalam domain dan forcing pasang surut diletakkan di sepanjang batas terbuka di arah barat, timur, utara dan selatan. Forcing pasang surut geopotensial untuk $\mathrm{M}_{2}, \mathrm{~S}_{2}, \mathrm{~N}_{2}$ dan $\mathrm{K}_{2}$ (empat konstituen semidiurnal terbesar) dan untuk $\mathrm{K}_{1}, \mathrm{O}_{1}, \mathrm{P}_{1}$ dan $\mathrm{Q}_{1}$ (empat konstituen diurnal terbesar) serta dua periode panjang gelombang Mf dan $\mathrm{Mm}$ dan satu konstituen non-linear $\mathrm{M}_{4}$ diekstraksi dari TPXO7 (Egbert dan Erofeeva 2002). Penelitian ini, masih menggunakan TPXO7 sebagai batas forcing pasang surut dari resolusi grid 1/4 karena secara eksplisit pasang surut dibangkitkan di dalam domain (Tranchan et al., 2016).

\subsubsection{Kasus Barotropik}

Pasang surut barotropikyang dihasilkan dalam kasus realistic dibandingkan dengan kasus barotropik (BT) tiga dimensi. Dalam hal ini, suhu air diatur $20^{\circ} \mathrm{C}$ dan salinitas adalah 32 PSU. Densitas dihitung menggunakan fungsi linear dari suhu:

$\rho=\rho_{0} *\left(0,028-r_{\alpha} * T\right)+\rho_{0}$ adalah densitas dasar dengan nilai $1020 \mathrm{kgm}^{-}$ 3 dan $r_{\alpha}=2 \times 10^{-4}$. Empat komponen pasang surut $\left(\mathrm{M}_{2}, \mathrm{~K}_{1}, \mathrm{~S}_{2}, \mathrm{O}_{1}\right)$ diekstrak dari TPXO7 dan digunakan sebagai forcing pasang surut. Model dijalankan untuk periode waktu yang sama (31 hari) dengan forcing pasang surut hanya pada bagian batas. Keluaran model seperti resolusi horizontal dan vertikal dan gesekan dasar adalah sama seperti pada kasus realistik.

\subsubsection{Kasus Baroklinik}

Pasang surut Internal dan pasang surut barotropik yang dihasilkan dalam kasus realistik dibandingkan dengan konstanta tiga dimensi dalam densitas pada kasus baroklinik (BC). Dalam hal ini, profil suhu dan salinitas awal menggunakan stratifikasi rata-rata 5 tahun dari model INDO12, densitas awal dari model pasang surut baroklinik secara horizontal homogen dan secara vertikal terstratifikasi. Empat komponen pasang surut $\left(\mathrm{M}_{2}, \mathrm{~K}_{1}, \mathrm{~S}_{2}, \mathrm{O}_{1}\right)$ diekstrak dari TPXO7 dan digunakan sebagai forcing pasang surut. Model dijalankan untuk periode waktu yang sama (31 hari) dengan forcing pasang surut hanya pada bagian batas.
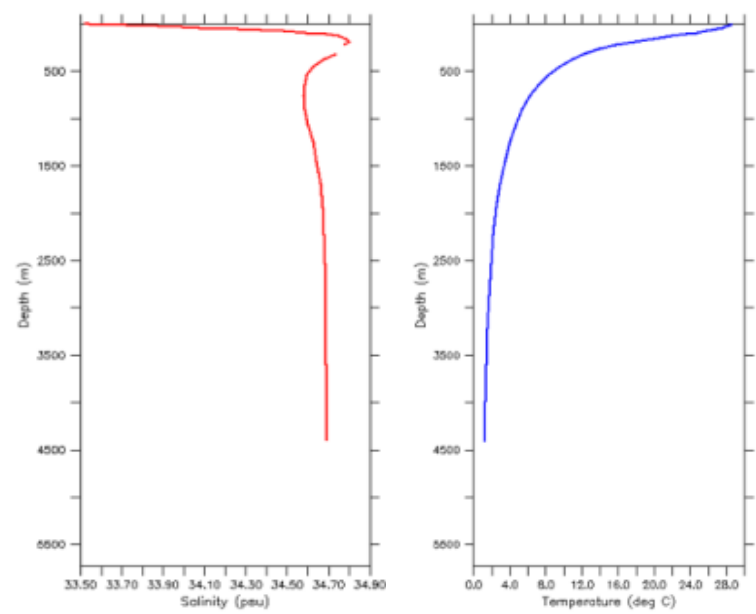

Gambar 2. Profil salinitas dan temperaturlaut Sulawesi yang digunakan dalam simulasi BC (periode 2008-2013).

\subsubsection{Persamaan Energi Pasang Surut Internal}

Pasang surut Barotropik didefinisikan sebagai mode-0 dan pasang surut internal 
adalah jumlah dari mode eigen vertikal dari mode-1. Komponen semidiurnal dan diurnal (bagian perturbasi harmonik) dihitung menggunakan perangkat lunak toolbox pasang surut. Keluaran model 3D dari kecepatan dan densitas rata-rata 31-hari dari setiap simulasi dipasang pada frekuensi komponen semidiurnal $\left(\mathrm{M}_{2}, \mathrm{~S}_{2}\right)$ dan diurnal $\left(\mathrm{K}_{1}, \mathrm{O}_{1}\right)$ menggunakan metode kuadrat terkecil (Least Square). Tekanan total didekomposisi menjadi tekanan permukaan $P_{s}$ dan perturbasi densitas $\left(P_{\text {hyd }}\right)$ :

$P=P_{s}+P_{h y d}$

$P_{s}=\rho_{0} g \eta$

Keterangan: $P_{S}$ dan $P_{\text {hyd }}$ adalah tekanan permukaan dan hidrostatik.

Tekanan hidrostatik dapat ditentukan dari gradient tekanan hidrostatik:

$P_{h y d}=\int_{d}^{\eta} \rho^{\prime} g d z^{\prime}$

Suatu model tidak terstratifikasi, variasi dari tekanan adalah konstan, sehingga tekanan hidrostatik sama dengan tekanan permukaan. Disipasi baroklinik dapat diestimasi dari relasi energi pasang surut rata-rata periode (Nugroho 2017):

$\overline{E k_{l t}}=\int_{d}^{\eta} \nabla_{h} \overline{\boldsymbol{v}^{\prime} p}-\left(\overline{\boldsymbol{v}} p^{\prime}\right)_{z=-h} \nabla_{H} d+D_{i t} \ldots \ldots$

\subsection{Validasi Model}

\subsubsection{Semimajor Axis Velocity}

Propagasi pasang surut barotropik dalam INDO12 memiliki perbandingan yang bagus dengan titik crossing antara TPX/J1/J2 dan Finite Elemen Solution (FES2012), kesesuaian tersebut terlihat pada hasil frekuensi signal pasang surut yang diambil pada 3 titik lokasi (Tranchant et al., 2016). Pasang surut barotropik yang dihasilkan dalam simulasi realistik dibandingkan dengan perhitungan dari FES2014, hal ini terlihat pada hasil perbandingan semimajor axis velocity seperti yang ditunjukkan pada
Gambar 3 untuk pasang surut barotropik komponen $\mathrm{M}_{2}$ dan $\mathrm{K}_{1}$ antara simulasi kasus realistik dari INDESO dan FES2014. FES2014 menggunakan semua forcing pasang surut $\mathrm{M}_{2}$ dan $\mathrm{K}_{1}$ seperti potensial pasang surut dan proses pergerakannya, tetapi dalam simulasi realistik hanya dibangkitkan melalui potensial pasang surut dan forcing pasang berada di bawah batas terbuka. Kecepatan arus yang tinggi pada kedua model mengindikasikan bahwa terdapat disipasi bagian bawah yang kuat yang ditemukan pada suatu area. Disipasi pasang ditemukan lebih tinggi dalam FES 2014 untuk area Sangihe-Talaud. Disipasi pasang bisa dihubungkan dengan gesekan dasar atau pembangkitan pasang surut internal.

Langkah validasi selanjutnya adalah menghitung komponen tidal ellipseyang ditentukan melalui analisis harmonik dari arus barotropik pada setiap titik model dan pengamatan (Tabel 1). Komponen pasut $\mathrm{M}_{2}$ dan $\mathrm{K}_{1}$ menjadi komponen yang dominan pada signal arus barotropik.

Ekstrak hasil NEMO pada masingmasing titik dan membandingkannya dengan data lapangan (FES2014). Komponen harmonik pasut M2 dari model dan observasi untuk kecepatan pasang surut barotropik dibandingkan melalui perhitungan RootMean-Square Error (RMSE) dengan menggunakan rumus (Cummins and Oey 1997):

$R M S E=$
$\sqrt{0,5\left(A_{o}^{2}+A_{m}^{2}\right)-A_{o} A_{m} \cos \left(G_{o}-G_{m}\right)} \ldots$.

Keterangan: $A_{o}$ dan $A_{m}$ adalah amplitudo observasi dan model, $G_{o}$ dan $G_{m}$ adalah phase observasi dan model.

Berdasarkan (Tabel 2) terlihat bahwa nilai RMSE perbandingan antara data INDESO dan FES2014 memiliki nilai yang sangat kecil dengan rata-rata 0,002845 , hal ini menunjukkan bahwa hasil estimasi model yang dihasilkan semakin tepat bila dibandingkan dengan pengamatan. 

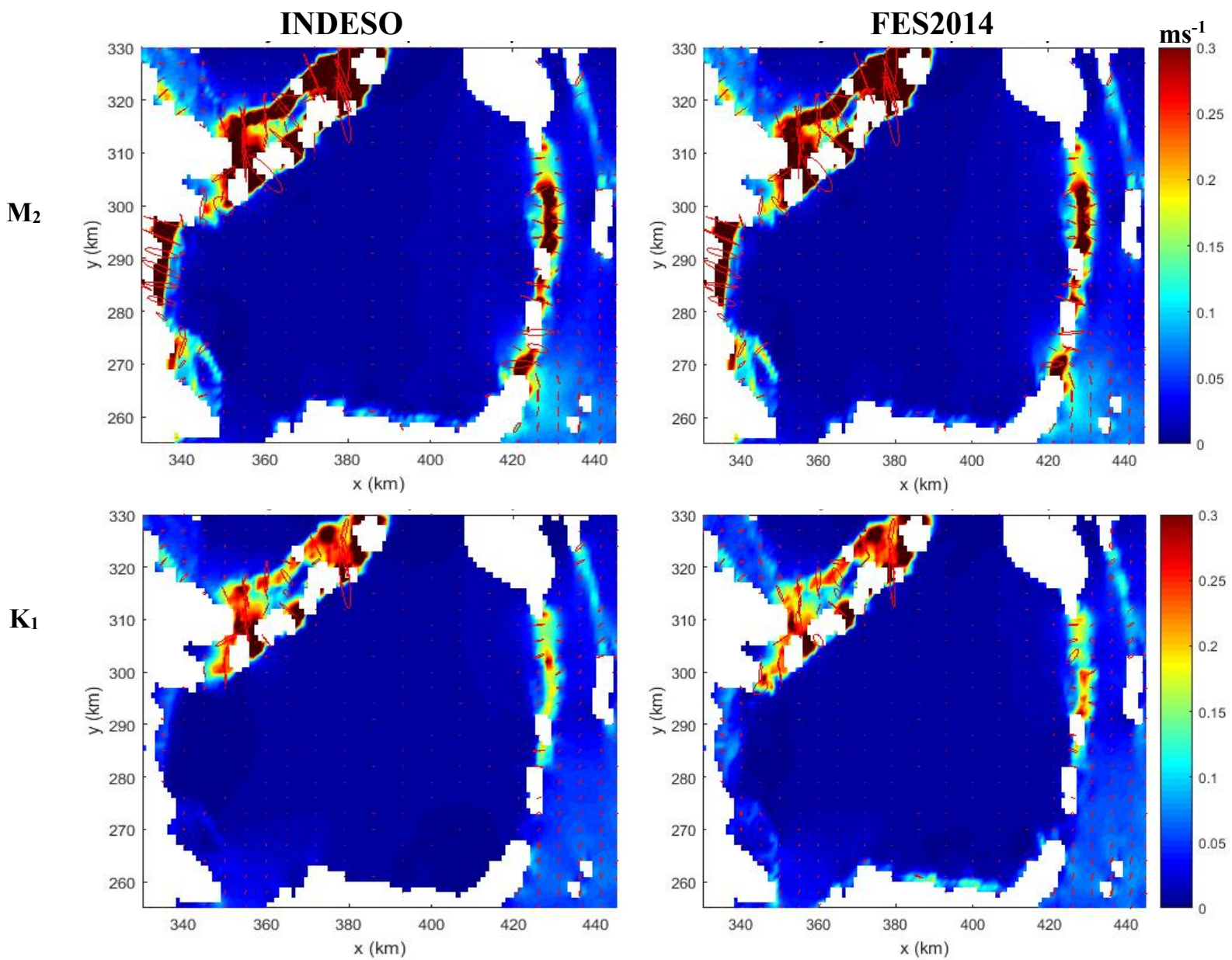

Gambar 3. Perbandingan semimajor axis velocity $\mathrm{M}_{2}$ dan $\mathrm{K}_{1}$ antara simulasi INDESO (kiri) dan FES2014 (kanan).

Tabel 1. Nilai Tidal Ellipse yang diturunkan dari analisis harmonik arus pasang surut barotropik.

\begin{tabular}{lcccccccc}
\hline \multirow{2}{*}{$\begin{array}{c}\text { Komponen } \\
\text { Pasut }\end{array}$} & \multicolumn{2}{c}{$\begin{array}{c}\text { Major Axis } \\
(\mathrm{cm} / \mathrm{s})\end{array}$} & \multicolumn{2}{c}{$\begin{array}{c}\text { Minor Axis } \\
(\mathrm{cm} / \mathrm{s})\end{array}$} & \multicolumn{2}{c}{ PHASE } & \multicolumn{2}{c}{ INC } \\
\cline { 2 - 9 } & \multirow{2}{*}{ INDESO } & FES & INDES & FES & INDES & FES & INDE & FES \\
& 2014 & $\mathrm{O}$ & 2014 & $\mathrm{O}$ & 2014 & SO & 2014 \\
\hline $\mathrm{M}_{2}$ & 61,16 & 68,12 & 15,57 & 16,63 & 139,16 & 143,33 & 73,93 & 74,41 \\
$\mathrm{~K}_{1}$ & 59,60 & 56,03 & 2,22 & 8,35 & 229,21 & 235,89 & 60,71 & 67,56 \\
\hline
\end{tabular}

Tabel 2. Nilai root mean square error (RMSE).

\begin{tabular}{ccccccc}
\hline \multicolumn{2}{c}{ Jarak } & \multicolumn{2}{c}{ Amplitudo } & \multicolumn{2}{c}{ Phase } & \multirow{2}{*}{ RMSE } \\
\cline { 1 - 5 } $\mathrm{x}(\mathrm{km})$ & $\mathrm{y}(\mathrm{km})$ & INDESO & FES 2014 & INDESO & FES 2014 & \\
\cline { 1 - 5 } 330 & 285 & 0,26 & 0,27 & 265,18 & 265,18 & 0,0054 \\
345 & 285 & 0,00 & 0,01 & 43,73 & 43,73 & 0,0003 \\
355 & 294 & 0,00 & 0,00 & 37,27 & 37,27 & 0,0001 \\
365 & 273 & 0,01 & 0,01 & 71,69 & 71,69 & 0,0004 \\
\hline
\end{tabular}




\begin{tabular}{ccccccc}
\hline \multicolumn{2}{c}{ Jarak } & \multicolumn{2}{c}{ Amplitudo } & \multicolumn{2}{c}{ Phase } & \multirow{2}{*}{ RMSE } \\
\cline { 1 - 5 } $\mathrm{x}(\mathrm{km})$ & $\mathrm{y}(\mathrm{km})$ & INDESO & FES 2014 & INDESO & FES 2014 & \\
\hline 379 & 261 & 0,02 & 0,02 & 59,42 & 59,42 & 0,0029 \\
386 & 309 & 0,01 & 0,01 & 77,63 & 77,63 & 0,0004 \\
400 & 291 & 0,01 & 0,01 & 58,17 & 58,17 & 0,0006 \\
414 & 267 & 0,01 & 0,01 & 44,64 & 44,64 & 0,0005 \\
426 & 267 & 0,05 & 0,07 & 223,98 & 223,98 & 0,0097 \\
436 & 255 & 0,01 & 0,01 & 216,75 & 216,75 & 0,0003 \\
441 & 309 & 0,05 & 0,05 & 73,81 & 73,81 & 0,0026 \\
445 & 330 & 0,00 & 0,00 & 65,71 & 65,71 & 0,0004 \\
\hline
\end{tabular}

\subsubsection{Fluks Energi}

Energi $\mathrm{M}_{2}$ yang berasal dari Samudra Hindia diarahkan ke utara, melintasi pulaupulau nusa tenggara melalui Makassar dan Selat Sibutu (Egbert and Erofeeva 2002). Simulasi realistis, energi fluks di wilayah tersebut memiliki tanda yang berlawanan. Energi fluks pasang surut sangat bergantung pada kondisi topografi bawah. Perbedaan resolusi grid dan input topografi bawah dapat menghasilkan besaran fluks energi yang berbeda. Jackson (2007) melakukan penelitian dengan menggunakan metode Survei Citra Satelit aqua MODIS dan ditemukan aktivitas gelombang internal yang signifikan dari Februari sampai Desember di Laut Sulawesi. Gelombang tersebut menampakkan diri sebagai gelombang soliter sebanyak 3 sampai 5 paket gelombang yang mengalami propagasi melewati laut bagian tenggara dan barat. Perbandingan fluks energi dapat ditunjukkan melalui hasil pengamatan dengan data satelit sebagaimana yang dilakukan oleh Jackson (2007) dan juga Snapshots Model kecepatan vertikal pada kedalaman $1000 \mathrm{~m}$ seperti yang disajikan pada Gambar 4.

Hasil penelitian Jackson (2007) yang disajikan dalam Gambar 4. menjelaskan bahwa propagasi gelombang bagian tenggara berasal dari Kepulauan Sulu sedangkan propagasi gelombang Barat berasal dari tepi timur laut, kemungkinan besar di dekat Kepulauan Sangihe-Talaud. Gelombang terjadi secara semidiurnal dengan kecepatan propagasi sekitar $3,0 \mathrm{~m} / \mathrm{s}$ melewati area (a)

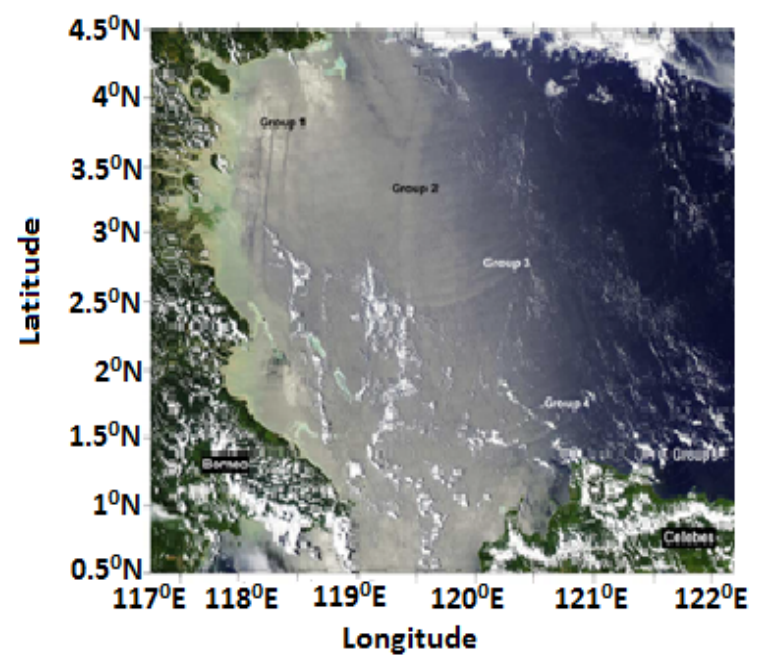

(b)

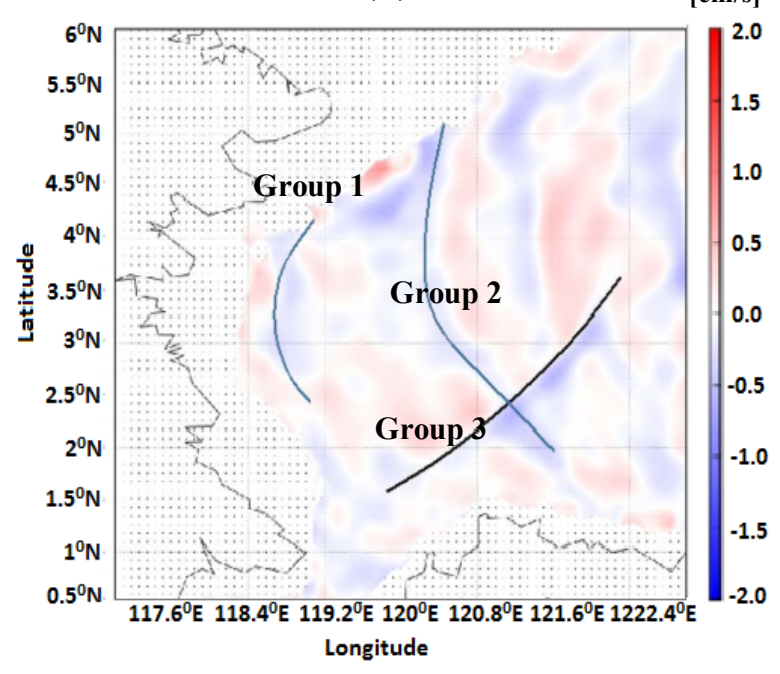

Gambar 4. Perbandingan antara fluksenergi antara (a) Pengamatan Citra MODIS (Jackson, 2007), (b) SnapshotsModel Kecepatan Vertikalpada kedalaman 1000 m. 
basin Laut Sulawesi yang dalam. Snapshot model kecepatan vertikal yang disimulasi pada kedalaman $1000 \mathrm{~m}$ menunjukkan pola propagasi gelombang yang sama, yaitu sumber pembangkitan gelombang internal berasal dari Kepulauan Sangihe-Talaud dan Kepulauan Sulu, group 1 dan 2 berpropagasi menuju ke arah barat mendekatai Pulau Kalimantan, sedangkan group 3 berpropagasi menuju pesisir Pulau Sulawesi.

\section{HASIL DAN PEMBAHASAN}

\subsection{Pembangkitan Gelombang Internal}

Konversi pasang surut barotropik ke baroklinik terjadi terutama di Kepulauan Sulu dan Sangihe-Talaud (Gambar 5). Pada beberapa area yang jauh dari pusat pembangkitan dalam hal ini area basin Laut Sulawesi, konversi energi yang terjadi sangat lemah yaitu kurang dari $10^{-3} \mathrm{Wm}^{-2}$. Nilai negatif dari tingkat konversi energi di beberapa lokasi menunjukkan bukti adanya pembangkitan gelombang internal, yang merupakan hasil dari perbedaan fase antara gelombang internal yang dihasilkan secara internal dan dari area yang jauh (Zilberman et al., 2009). Berdasarkan Gambar 5 konversi energi tinggi terjadi pada area Kepulauan Sulu dan Sangihe-Talaud, konversi energi bernilai negatif menandakan pada area tersebut terjadi pembangkitan

(a) $\mathrm{M}_{2}$

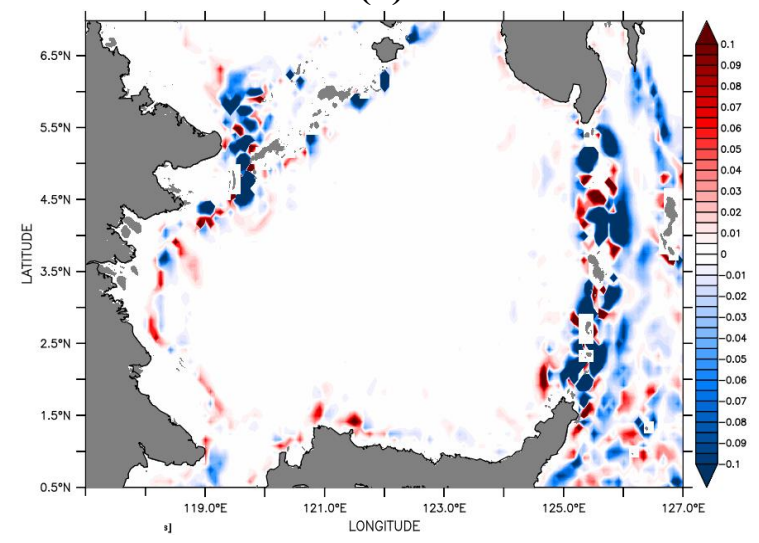

gelombang internal. Namun terlihat bahwa konversi energi pada komponen $\mathrm{M}_{2}$ lebih besar dibandingkan dengan konversi energi pada komponen $\mathrm{S}_{2}$. Konversi negatif yang signifikan terjadi dalam area Kepulauan sulu dan Sangihe-Talaud kemungkinan terjadi karena adanya tarikan energi baroklinik yang dihasilkan secara lokal berinteraksi dengan yang dihasilkan di wilayah Utara Kepulauan Sangihe-Talaud di Laut Mindanao.

Tingkat konversi energi yang disajikan pada Gambar 5 memperlihatkan bahwa komponen $\mathrm{K}_{1}$ memliki nilai yang lebih tinggi dari pada komponen $\mathrm{O}_{1}$ untuk komponen pasut diurnal. Sama halnya dengan komponen $\mathrm{M}_{2}$ dan $\mathrm{S}_{2}$, pada komponen $\mathrm{K}_{1}$ dan $\mathrm{O}_{1}$ konversi energi barotropik ke baroklinik tinggi pada daerah Kepulauan Sulu dan Sangihe-Talaud. Hal ini sejalan dengan hasil penelitian yang dilakukan Egbert and Erofeeva (2002), bahwa rata-rata konversi barotropik di Laut Sulawesi didominasi oleh komponen $\mathrm{M}_{2}$ dan $\mathrm{K}_{1}$. Tingkat konversi energi barotropik sebesar 85,5 GW di Kepulauan Indonesia setara dengan sekitar $8 \%$ dari tingkat konversi global dari pasang semidiurnal yang diperkirakan oleh Niwa dan Hibiya (2014) dan sekitar 4\% dari kekuatan yang diperlukan untuk mempertahankan sirkulasi thermohalin global (Munk dan Wunsch, 1998).

\section{(b) $\mathrm{K} 1$}

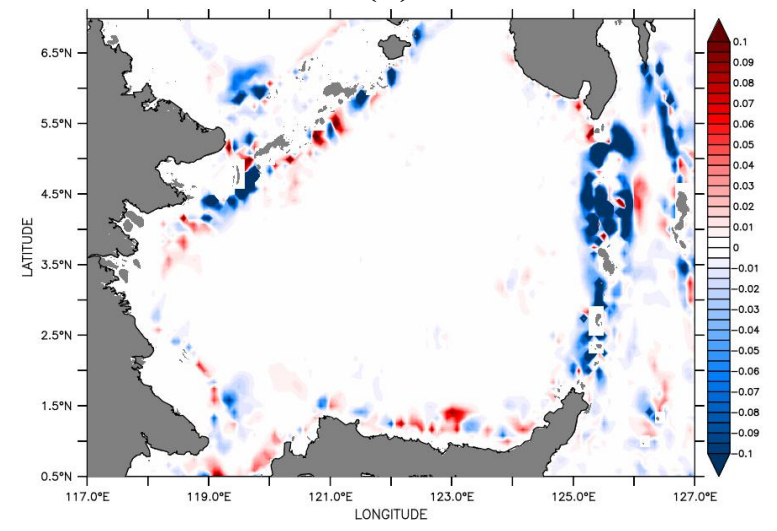

Gambar 5. Konversi energi terintegrasi kedalaman dan rataan-waktu $(\mathrm{Ct})$ dalam satuan $W m^{-2}$ untu kModel $\mathrm{M}_{2}$ (a) dan $\mathrm{K}_{1}$ (b). 
Konversi barotropik ke baroklinik terjadi terutama di celat sempit Kepulauan Sulu dan Pulau Sangihe. Di banyak daerah yang jauh dari lokasi pembangkitan, konversi energi lemah kurang dari $10^{-3} \mathrm{Wm}^{-2}$ ditemukan. Perhatikan bahwa nilai negatif dari tingkat konversi energi di beberapa lokasi menunjukkan bukti untuk beberapa areapembangkitan, karena adanya hasil dari perbedaan fase antara gelombang internal yang dihasilkan secara internal dan jarak jauh (Zilberman et al., 2009).

\subsection{Propagasi}

Proses propagasi dan disipasi dalam 'far-field' '(di luar near-field) dapat dengan jelas dilihat dalam snapshot dari tingkat disipasi energi baroklinik rata-rata kedalaman di Laut Sulawesi. Disipasi energi gelombang internal berasal dari Kepulauan Sulu dan Sangihe-Talaud menjadi lebih signifikan seperti radiasi yang menjalar menjauhi pulau.Hal ini sejalan dengan apa yang dijelaskan oleh Nagai et al. (2015) bahwa hasil propagasi gelombang internal ini berangsur-angsur berevolusi menjadi gelombang yang mirip soliter sambil meningkatkan jumlah gelombang horizontalnya, dan tingkat disipasi energi yang terkait dengan gelombang soliter mencapai lebih dari $10^{-8} \mathrm{~W} \mathrm{~kg}^{-1}$ yang hanya 1 atau 2 kali lebih kecil dari yang ada di near-field (area pusat pembangkitan). Paket gelombang internal yang mirip soliter ini dipancarkan dari Kepulauan Sulu dan Sangihe-Talaud dan terlihat menyebar secara bebas tanpa berinteraksi satu sama lain.

Fluk senergi barotropik yang tinggi terlihat dekat celah Kepulauan SangiheTalaud seperti pada Gambar 6. fluks energi $\mathrm{M}_{2}$ dominan melewati area yang dangkal. Dalam simulasi kasus realistik, fluks energi dalam wilayah ini memiliki tanda yang berlawanan. Fluks energi pasang surut sangat bergantung pada kondisi topografi dasar. Perbedaan resolusi grid dan input topografi dasar bisa membangkitkan besaran yang berbeda dari fluks energi.

Fluks energi barotropik di Laut Sulawesi oleh komponen $\mathrm{M}_{2}$ dan $\mathrm{K}_{1}$, Gambar 6 memperlihatkan bahwa untuk komponen $\mathrm{M}_{2}$ masuk melalui celah bagian selatan Kepulauan Sangihe-Talaud dan berpropagasi sebagian menuju kearah barat daya menuju ke arah Kepulauan Sulu dan sebagian lainnya masuk ke wilayah perairan Selat Makassar, sedangkan komponen $\mathrm{K}_{1}$, fluks barotropik masuk melalui celah bagian utara Kepulauan Sangihe-Talaud dan berpropagasi menuju ke arah utara mendekati area Kepulauan Sulu, sebagian yang lain berpropagasi menuju ke arah barat mendekati Pulau Borneo dan masuk ke wilayah perairan Selat Makassar. Hasil penelitian ini sejalan dengan apa yang ditemukan oleh Egbert and Erofeeva (2002), bahwa fluks energi barotropik $\mathrm{M}_{2}$ berasal dari Samudera Hindia sehingga mendekati laut Sulawesi masuk melalui celah bagian

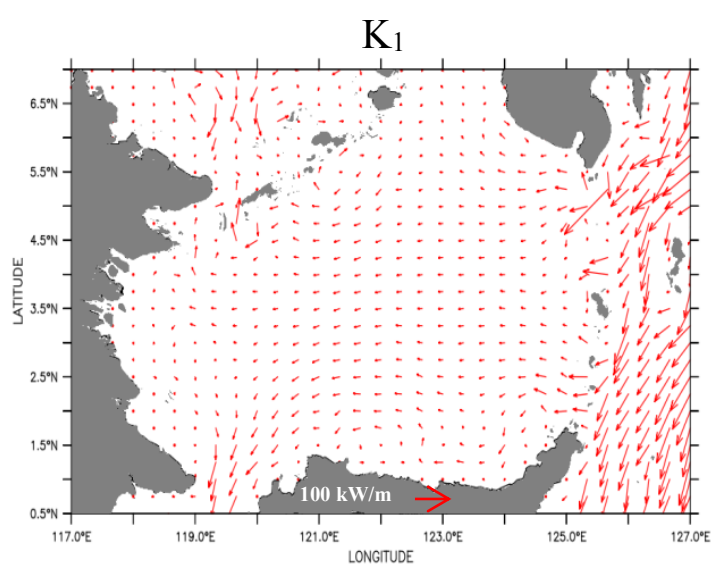

Gambar 6. Perbandingan fluks barotropik antara komponen $\mathrm{M}_{2}$ dan $\mathrm{K}_{1}$. 
selatan, sedangkan komponen $\mathrm{K}_{1}$ berasal dari Samudera Pasifik sehingga arus barotropik masuk melalui celah bagian utara Kepulauan Sangihe-Talaud.

\subsection{Struktur Spasial}

Gambar 7 mengilustrasikan distribusi horizontal dari vektor fluks energi baroklinik terintegrasi-kedalaman. Fluks yang tinggi terlihat di sekitar dua fitur topografi, yang meliputi wilayah Kepulauan Sulu dan Sangihe-Talaud. Energi baroklinik yang besar dapat dilihat memancar (radiasi) dari Kepulauan Sulu dan Sangihe-Talaud. Efek ini juga ditunjukkan oleh Nagai et al. (2015). Disipasi energi baroklinik yang besar terjadi di dekat lokasi pembangkitan pasang internal yang kuat.

Aliran energi baroklinik yang kuat diidentifikasi terjadi pada Rangkaian Kepulauan Sangihe-Talaud, sebagian besar energi tersebut didisipasi menjadi percampuran lokal. Hal ini sejalan dengan penelitian Nagai et al. (2015) bahwa lebih dari $10 \mathrm{~kW} / \mathrm{m}$ energy berasal dari daerah di mana konversi energi signifikan diidentifikasi (Rangkaian Kepulauan SangiheTalaud dan Kepulauan Sulu). Lebih lanjut Nagai et al. (2015) menjelaskan bahwa sebagian besar energi baroklinik yang

(a) $\mathrm{M}_{2}$

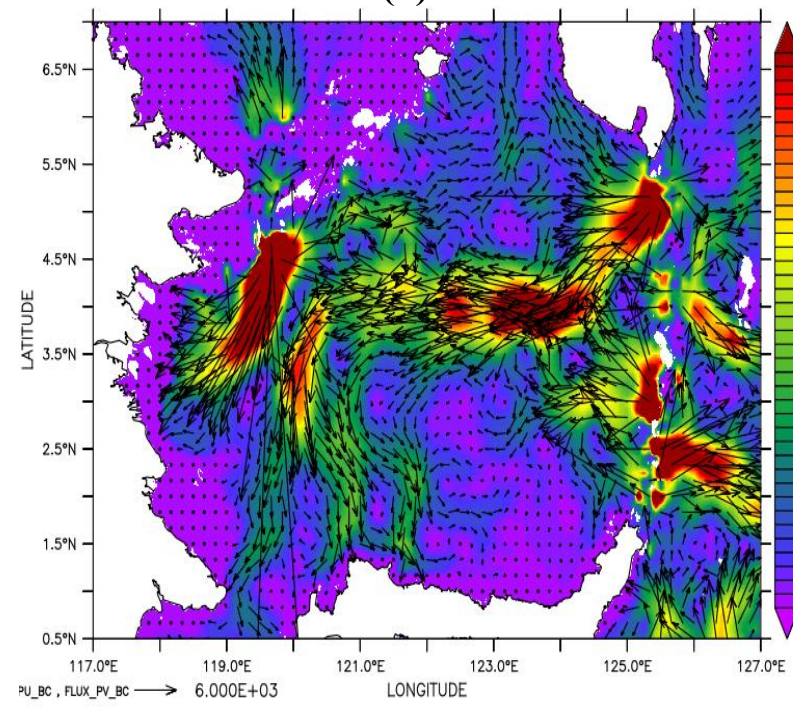

dihasilkan dibuang di daerah dekat pantai pulau-pulau di kepulauan Indonesia, meninggalkan hanya sebagian kecil energi $(3,6$ GW) memancar keluar dari Kepulauan Indonesia.

Gambar 8 memperlihatkan divergen dari fluks energi baroklinik yang terintegrasi kedalaman. Nilai divergen yang besar terjadi pada area dimana lokasi pembangkitan gelombang internal terjadi yaitu pada area Kepulauan Sulu dan Sangihe-Talaud. Peningkatan fluks yang tinggi ini kemungkinan terjadi karena adanya proses konversi energi dari barotropik ke baroklinik yang besar pada area pusat pembangkitan.

Laut Sulawesi, struktur seperti sinar diidentifikasi di sekitar rangkaian Kepulauan Sangihe-Talaud (500 km $<\mathrm{x}<620 \mathrm{~km}$ ), meskipun akhirnya menghilang setelah adanya beberapa pantulan (refleksi) dari permukaan dan dasar laut, yang dihasilkan dari disipasi oleh mode vertikal yang tinggi. Sangat menarik untuk dicatat bahwa, di Laut Sulawesi gelombang internal yang energik ini berevolusi secara berangsur-angsur menjadi gelombang yang menyerupai soliter ketika berpropagasi jauh dari lokasi pembangkitan. Fenomena ini juga sudah dideteksi oleh Jackson (2007) melalui pengamatan satelit Citra Aqua MODIS.

Gambar 7. Perbandingan fluks baroklinik simulasi realistik $\mathrm{M}_{2}$ (a) dan $\mathrm{K}_{1}$ (b). 
(a)

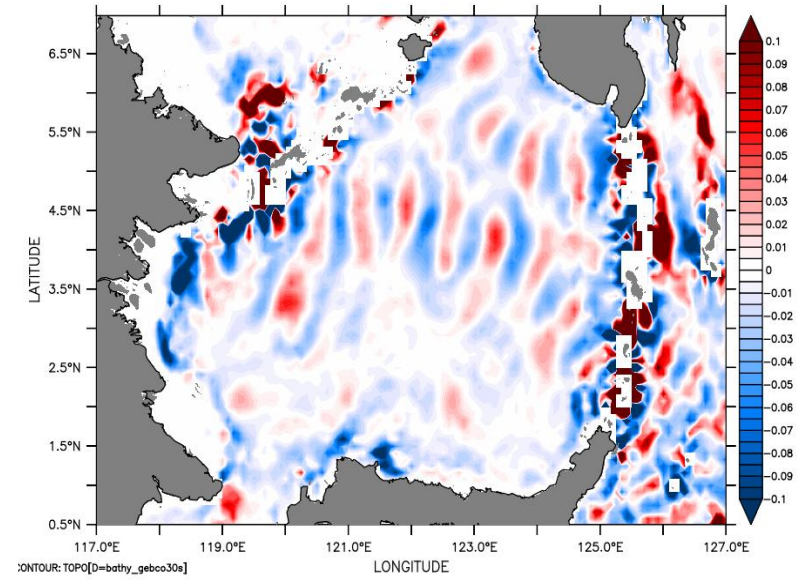

(b)

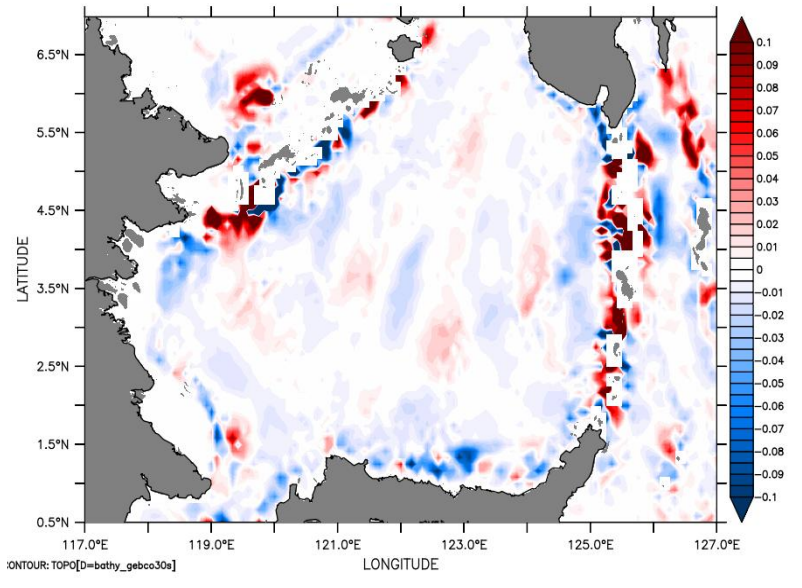

Gambar 8. Divergen fluks energi baroklinik $\left(\mathrm{Wm}^{-2}\right)$ untuk (a) komponen $\mathrm{M}_{2}$ dan (b) Komponen $\mathrm{K}_{1}$.

\subsection{Disipasi}

Konversi energi yang tinggi terjadi di area Sangihe-Talaud, daerah dimana terdapat sill (ambang) dengan kedalaman $1350 \mathrm{~m}$ (Gordon, 2003a) dan juga pada celah Kepulauan Sulu yang memungkinkan terjadinya proses disipasi (pelepasan energi), disipasi yang tinggi pada area sill (ambang) tersebutsangat berpengaruh penting terhadap proses pencampuran massa air. Gambar 9 menyajikan disipasi energi melalui gesekan dasar (drag). Distribusi tingkat disipasi energi baroklinik terintegrasi-kedalaman ditunjukkan pada Gambar 9, disipasi energi yang signifikan terjadi di dekat Kepulauan Sulu dan Sangihe-Talaud, yaitu sekitar setengah panjang gelombang horizontal dari gelombang internal modus terendah $(65 \mathrm{~km})$ dari lokasi pembangkitannya ("near-field").

Proses propagasi dan disipasi dalam "far-field"(di luar area pembangkitan) dapat dengan jelas dilihat dalam Gambar 9dari tingkat. Disipasi energi gelombang internal berasal dari Kepulauan Sulu dan SangiheTalauddan menjadi lebih signifikan pada saat berpropagasi dan terlihat seperti radiasi (sinar) yang menjalar menjauhi pulau. Hal ini karena gelombang internal ini berangsurangsur berevolusi menjadi gelombang yang mirip soliter sambil meningkatkan jumlah gelombang horizontalnya. Hal ini sejalan dengan penelitian Nagai et al. (2015) yang
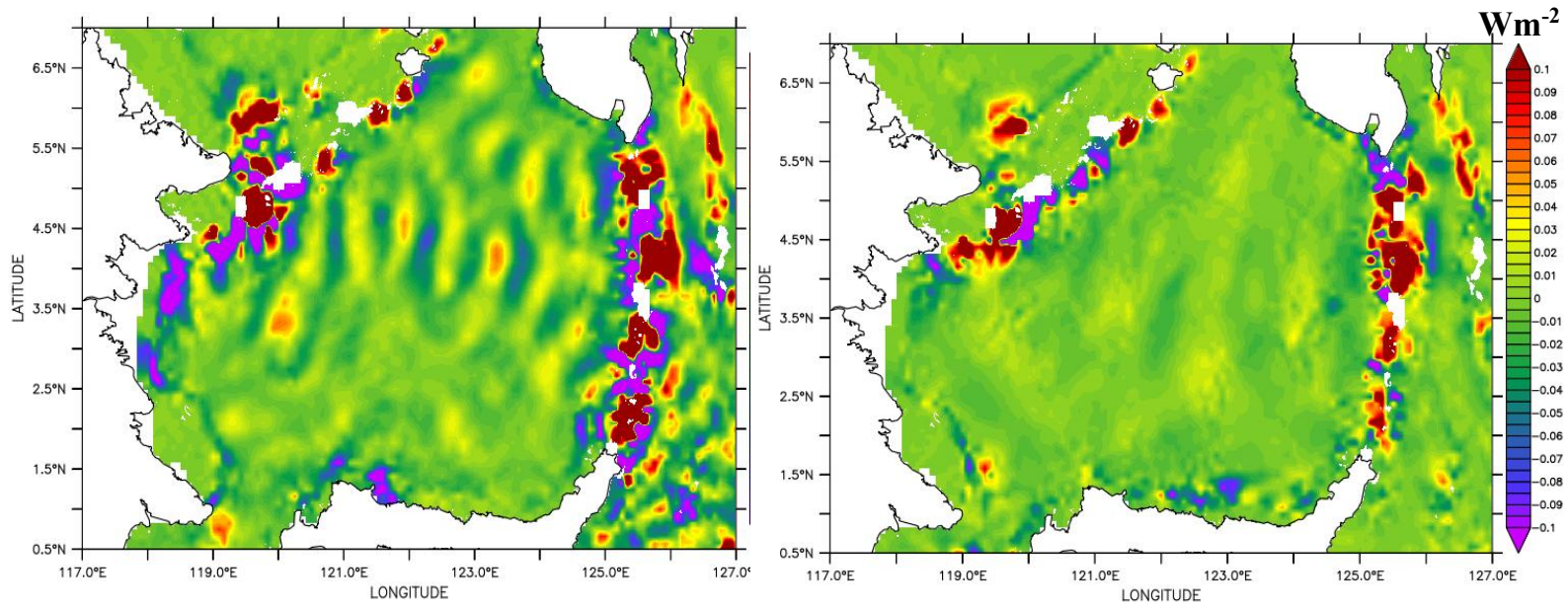

Gambar 9. Total disipasi energi yang disebabkan oleh gesekan dasar untuk (a) $\mathrm{M}_{2}$, (b) $\mathrm{K}_{1}$. 
Tabel 3. Total disipasi energi pada area lokal, near-field, dan far-field dari pusat pembangkitan gelombang internal (GW).

\begin{tabular}{lcccccc}
\hline Jarak $(\mathrm{Km})$ & 9 & 18 & 27 & 36 & 45 & 54 \\
\hline Lokal & 10,8 & 10,8 & 10,8 & 10,8 & 10,8 & 10,8 \\
Far-field & 4,8 & 3,5 & 2,6 & 2,1 & 1,8 & 1,4 \\
Near-field & 3,9 & 5,2 & 6,1 & 6,5 & 6,9 & 7,2 \\
Total & 19,5 & 19,5 & 19,5 & 19,5 & 19,5 & 19,5 \\
\hline
\end{tabular}

menjelaskan bahwa tingkat disipasi energi yang terkait dengan gelombang soliter mencapai lebih dari $10^{-8} \mathrm{~W} \mathrm{~kg}^{-1}$ yang hanya 1 atau 2 kali lipat lebih kecil dari yang ada di area pusat pembangkitan. Paket gelombang internal yang mirip soliter ini dipancarkan dari Pulau Sulu dan Pulau Sangihe-Talaud terlihat menyebar secara bebas tanpa berinteraksi satu sama lain. Meskipun masingmasing paket gelombang internal bertahan dan berpropagasi menjauhi pulau, itu memberikan sejumlah besar energi untuk disipasi selama propagasi. Hal ini disebabkan karena tingginya radiasi yang terjadi dari energi pasang surut baroklinik menjadi gelombang internal. Keberadaan sill di wilayah Sangihe-Talaud yang curam kemungkinan juga menjadi faktor utama kuatnya konversi dan radiasi energi baroklinik yang terjadi.

Total energi disipasi pada area lokal, area pusat pembangkitan gelombang internal (near-field), dan area basin Laut Sulawesi disajikan pada Tabel 3 (Nugroho, 2017). Disipasi energi yang terjadi pada pusat pembangkitan berkisar 10,8 GW dan berpopagasi pada area near-field dan farfield. Disipasi yang terjadi dalam area "near field" didefinisikan dalam jarak 6 titik dari pusat pembangkitan atau sekitar $54 \mathrm{~km}$. Sekitar 25\% (5 GW) didisipasi dekat dengan pusat pembangkitan (near-field), terjadi peningkatan disipasi energi baroklinik pada saat gelombang internal berpopagasi menjauhi daerah pusat pembangkitan dengan fitur topografi yang kasar (Sill). Total disipasi energi pada area "far field" bervariasi antara 1,4 sampai 4,8 GW, pada daerah dengan jarak $36 \mathrm{~km}$ sampai $54 \mathrm{~km}$ terjadi penurunan disipasi energi baroklinik. Signal utama dari disipasi bagian selatan Laut Sulawesi, dengan nilai $10^{-2} \mathrm{~W} / \mathrm{m}^{2}$, dengan pasang surut internal datang dari Selat Sibuttu dan Kepulauan SangiheTalaud. Signal yang kuat dari Kepualaun Sangihe berangsur menurun pada saat propagasi dan nilainya berkisar antara $10^{-}$ ${ }^{2}$ sampai $10^{-3} \mathrm{~W} / \mathrm{m}^{2}$.

\section{KESIMPULAN}

Konvesi energi sangat kuat terjadi pada area Kepulauan Sangihe-Talaud dan Sulu, hal ini terjadi karena adanya interaksi yang kuat antara arus pasang surut barotropik dengan sill yang curam pada kedua area tersebut. Sedangkan pada area basin Laut Sulawesi nilai konversi energi barotropik ke baroklinik menjadi lemah. Paket gelombang internal hasil dari radiasi pasang surut internal ini berpropagasi menjauhi area pembangkitan dan masuk ke area basin Laut Sulawesi, paket gelombang internal yang dibangkitkan pada area Sangihe-Talaud berpropagasi menuju ke arah barat dan mendekati Pulau Kalimantan dan sebagiannya menuju ke arah utara mendekatai Kepulauan Sulu, sedangkan hasil propagasi gelombang internal yang dibangkitkan di Sulu menuju ke arah Selatan mendekati Pulau Sulawesi. Kuatnya energi yang dikoversi dan diradiasi dari baroklinik dan juga keberadaan sill yang curam di SangiheTalaud kemungkinan memicu terjadinya transformasi paket gelombang internal menjadi gelombang soliter yang cukup kuat sehingga merambat sampai mendekati Pulau Kalimantan dan Sulawesi. 
Disipasi pasang surut bisa dihubungkan dengan gesekan dasar atau pembangkitan pasang surut internal. Distribusi tingkat disipasi energi baroklinik signifikan terjadi di dekat Kepulauan Sangihe-Talaud dan Sulu, yaitu sekitar setengah panjang gelombang horizontal dari gelombang internal modus terendah $(65 \mathrm{~km})$ dari lokasi pembangkitannya. Hasil disipasi dari energi pasang surut barotropik dan baroklinik ini akan memberikan implikasi yang cukup besar terhadap proses percampuran yang terjadi khususnya pada area Sangihe-Talaud dan Sulu, percampuran akibat disipasi pasang surut internal terjadi tepat $\mathrm{di}$ atas slope topografi. Selain itu, percampuran juga terjadi setelah gelombang internal yang berpropagasi pecah, hal ini terjadi akibat adanya vertikal shear instability, dimana gelombang internal merambat sepanjang isopycnal dan mengangkat massa air yang lebih berat ke atas.

\section{DAFTAR PUSTAKA}

Alford, M.H., T. Peacock, J.A. MacKinnon, J.D. Nash, M.C. Buijsman, L.R. Centuroni, Chao S-Y, M.H. Chang, D.M. Farmer, and O.B. Fringer. 2015. The formation and fate of internal waves in the South China Sea. Nature, 521:65-69. http://dx.doi.org/ 10.1038 /nature14399.

Arbic, B.K., A.J. Wallcraft, and E.J. Metzger. 2010. Concurrent simulation of the eddying general circulation and tides in a global ocean model. Ocean Mod., 32(3-4):175-187. http://dx.doi. org/10.1016/j.ocemod.2010.01.007.

Bell, T.H. 1975b. Topographically generated internal waves in the open ocean. $J$. Geophys. Res., 80:320-327. http://d x.doi.org/10.1029/JC080i003p00320.

Carter, G.S. 2010. Barotropic and baroclinic M2 tides in the Monterey Bay region. J. Phys. Oceanogr., 40:1766-1783. doi:10.1175/2010JPO4274.1
Carter, G.S., O. Fringer, and E. Zaron. 2012. Regional Models of Internal Tides. Oceanogr., 25(2):56-65.

Cummins, P.F. and L.Y. Oey. 1997. Simulation of barotropic and baroclinic tides off northern British Columbia, J. Phys. Oceanogr., 27(5):762-781. http://dx.doi.org/10. 1175/1520-0485(1997)027<0762:SO $\mathrm{BABT}>2.0 . \mathrm{CO} ; 2$.

Egbert, G.D. and R.D. Ray. 2000. Significant dissipation of tidal energy in the deep ocean inferred from satellite altimeter data. Nature, 405:775-778.

Egbert, G.D. and R.D. Ray. 2001. Estimates of M2 tidal energy dissipation from TOPEX/Poseidon altimeter data. $J$. Geophys. Res., 106(C10): 475-502.

Egbert, G.D. and S.Y. Erofeeva. 2002. Efficient inverse modeling of barotropic ocean tides. J. Atmos. Oceanic Technol., 19(2):183-204. http://dx. doi.org/10.1175/1520-0426(2002)019 $<0183$ :EIMOBO $>2.0 . \mathrm{CO} ; 2$.

Garrett, C. and E. Kunze. 2007. Internal tide generation in the deep ocean. Annu. Rev. Fluid Mech., 39:57-87. http://dx.doi.org/10.1146/annurev.flui d.39.050905. 110227.

Jachec, S.M., O.B. Fringer, M.G. Gerritsen, and R.L. Street. 2006. Numerical simulation of internal tides and the resulting energetics within Monterey Bay and the surrounding area. Geophys. Res. Lett., 33:L12605. http://dx.doi.org/10.1029/2006GL02 6314.

Jackson, C. 2007. Internal wave detection using the Moderate Resolution Imaging Spectroradiometer (MO DIS). J. Geophys. Res., 112(C11012). http://dx.doi.org/10.1029/2007JC004 220.

Jan, S., C.S. Chern, J. Wang, and S.Y. Chao. 2007. Generation of diurnal K1 internal tide in the Luzon Strait and its influence on surface tide in the South China Sea. J. Geophys. Res. 
Oceans, 112(6):1-13. http://dx.doi. org/10.1029/2006JC004003.

Jan, S., R.C. Lien, and C.H. Ting. 2008. Numerical study of baroclinic tides in Luzon Strait. J. Oceanogr., 64(5): 789-802.

Jhon, C., R. Christopher, Sherwood, G. Hernan, Arango, P. Richard, and Signell. 2005. Performance of four turbulence closure models implemented using a generic length scale method. Ocean Mod., 8:81-113. http://dx.doi.org/10.1016/j.ocemod.20 03.12.003.

Kang, D. and O. Fringer. 2012. Energetics of Barotropic and Baroclinic Tides in the Monterey Bay Area. J. Phys. Oceanogr., 42(2):272-290. http://dx. doi.org/10.1175/ 2010JPO4274.1.

Le Provost, C. 2003. Ocean tides after a decade of high precision satellite altimetry. Presentation in Swt JASON 1, Arles November 18-21.

Lyard, F., F. Lefevre, T. Letellier, O. Francis. 2006. Modelling the global ocean tides: Modern insights from FES 2004. Ocean Dyn., 56(5-6):394-415. http://dx.doi.org/10.1007/s10236-006 -0086-x.

Madec G. 2008. NEMO ocean engine. Perancis (FR): Note du Pole de modelisation, Institut Pierre-Simon Laplace (IPSL). 242 p.

Munk, W.H. and C. Wunsch. 1998. Abyssal recipes II: Energetics of tidal and wind mixing. Deep Sea Res., 45:1977-2010. http://dx.doi.org/10. 1016/S0967-0637(98)00070-3.

Nagai, T. and T. Hibiya. 2015. Internal tides and associated vertical mixing in the Indonesian Archipelago. J. Geophys. Res. Oceans, pages 3373-3390. http://dx.doi.org/10.1002/2014JC010 592.

Niwa, Y. and T. Hibiya. 2001. Numerical study of the spatial distribution of the M2 internal tide in the Pacific Ocean. J. Geophys. Res., 106:22441-22449.
http://dx.doi.org/10.1029/2000JC000 770.

Niwa, Y. and T. Hibiya. 2004. Threedimensional numerical simulation of M2 internal tides in the East China Sea. J. Geophys. Res., 109:C04027. http://dx.doi.org/10.1029/2003JC001 923.

Niwa, Y. and T. Hibiya. 2014. Generation of baroclinic tide energy in a global threedimensional numerical model with different spatial grid resolutions. Ocean Mod., 80:59-73. http://dx.doi. org/10.1016/j.ocemod.2014.05.003.

Nugroho, D. 2017. The tides in a generalized circulation model in Indonesian Seas. Perancis (FR). Universite de Toulouse. $161 \mathrm{p}$.

Nugroho, D., A. Koch-Larrouy, P. Gaspar, F. Lyard, G. Reffray, and B. Tranchant. 2017. Modelling explicit tides in the Indonesian seas: an important process for surface sea water properties, in revision. Mar Poll Bul., 131:7-18. http://dx.doi.org/10.1016/j.marpolbul. 2017.06.033.

Polzin, K.L., J.M. Toole, J.R. Ledwell, and R.W. Schmitt. 1997. Spatial varia bility of turbulent mixing in the Abyssal Ocean. Science, 276:93-96. http://dx.doi.org/10.1126/science.276. 5309.93.

Robertson, R. and A. Ffield. 2008. Baroclinic tides in the Indonesian seas: Tidal fields and comparisons to observations. J. Geophys. Res. Oceans, 113(7):1-22. http://dx.doi.org/10.10 29/2007JC004677.

St. Laurent, L. and C. Garrett. 2002. The role of internal tides in mixing the deep ocean. J. Phys. Oceanogr., 32:28822899. http://dx.doi.org/10.1175/15200485(2002)032<2882:TROITI $>2.0 . \mathrm{C}$ $\mathrm{O} ; 2$.

Tranchant, B., G. Reffray, E. Greiner, D. Nugroho, A. Koch-Larrouy, and P. Gaspar. 2016. Evaluation of an operational ocean model 
configuration at 1/12 spatial Zilberman, N.V., J.M. Becker, M.A. resolution for the Indonesian seas. Merrifield, and G.S. Carter. 2009. Ocean Phys., pages 1-49. http://dx. Model estimates of M2 internal tide doi.org/10.5194/gmdd-8-6611-2015. generation over mid-atlantic ridge Wang, X., S. Peng, Z. Liu, R.X. Huang, Qian Y-K, and Y. Li. 2016. Tidal mixing in the South China Sea: zn estimate based on the internal tide energetics. J. Phys. Oceanogr., 46(1):107-124. http://dx.doi.org/10.1175/JPO-D-150082.1 . topography. J. Phys. Oceanogr., 39:2635-2651. http://dx.doi.org/10.1 175/2008JPO4136.1.

Diterima : 23 April 2018

Direview : :02 Mei 2018

Disetujui : 05 Juli 2018 